\title{
Personalising pain management in advanced cancer: is KCNJ6 A1032G associated with methadone response?
}

Larisa Haupt ( $\square$ larisa.haupt@qut.edu.au )

Queensland University of Technology

Deniz Ozberk

Griffith University

Alison Haywood

Griffith University

Heidi Sutherland

Queensland University of Technology

Chieh Yu

Queensland University of Technology

Cassie Albury

Queensland University of Technology

Matthew Zunk

Griffith University

Rani George

Griffith University

Phillip Good

University of Queensland

Lyn Griffiths

Queensland University of Technology

Janet Hardy

Mater Health

\section{Research Article}

Keywords: Methadone, pain, cancer, opioids, KCNJ6 A1032G, rs2070995

Posted Date: March 7th, 2022

DOI: https://doi.org/10.21203/rs.3.rs-1371929/v1 
License: (c) (i) This work is licensed under a Creative Commons Attribution 4.0 International License. Read Full License 


\section{Abstract}

Opioids are the therapeutic agents of choice to manage moderate to severe pain in patients with advanced cancer, however the unpredictable inter-individual response to opioid therapy remains a challenge for clinicians. While studies are few, the $K C N J 6$ gene is a promising target for investigating genetic factors that contribute to pain and analgesia response. This is the first association study on polymorphisms in KCNJ6 and response to methadone for pain management in advanced cancer. Fiftyfour adult patients with advanced cancer were recruited across two study sites in a prospective, open label, dose individualisation study. No associations were shown for rs2070995 and methadone dose or pain score, consistent with other studies conducted in patients receiving opioids for pain in advanced cancer. Significant associations have been shown for rs2070995 and opioid response in opioid substitution therapy for heroin addiction and studies in chronic pain, with mixed results seen in postoperative pain. There are many challenges in conducting studies in advanced cancer with significant attrition and small sample sizes, however it is hoped that the results of our study will contribute to the evidence base and allow for continued development of gene-drug dosing guidelines for clinicians.

\section{Key Messages}

- Pain is the most feared symptom in advanced cancer

- Inter-patient variability in response to opioids makes dosing challenging in practice

- KCNJ6 gene a promising target for exploring genetic factors relating to pain response

- No significant associations shown for rs2070995 and methadone dose or pain score

- Studies are few, but contribute to evidence-based gene-drug dosing guidelines

\section{Introduction}

Cancers are among the leading causes of morbidity and mortality worldwide, and pain is the most debilitating symptom associated with cancer that can significantly impact quality of life [1]. Opioids are the therapeutic agents of choice to manage moderate to severe pain in patients with cancer in end-of-life [2], however the unpredictable inter-individual response to opioid therapy remains a challenge for clinicians [1]. Pharmacogenetics has been shown to be a promising approach to tailor treatment to an individual's genetic profile as cancer patients with a more favourable genetic background have been shown to respond better to opioids with a lower dose and fewer side effects $[3,4]$.

The $K C N J 6$ gene has been shown to be a promising target for investigating the genetic factors that contribute to pain and analgesia response [5]. KCNJ6 encodes for potassium inwardly rectifying channels, subfamily J, member 6 (GIRK2, Kir3.2). G-protein coupled inwardly rectifying potassium (GIRK) channels are activated by heterotrimeric $\mathrm{G}_{\mathrm{i} / \mathrm{o}}$ proteins after stimulation of opioid receptors by endogenous or exogenous opioids. This causes an efflux of potassium ions which hyperpolarize the membrane potential and dampen neuronal excitability thus limiting nociceptive transmission [6]. Due to the crucial 
function of GIRK channels in the therapeutic effect of opioids, it has been suggested that future analgesic agents may be developed to directly target GIRK channels [7-9].

Genetic variation in the KCNJ6 gene has been shown to influence opioid response [5], where the $\mathrm{G}$ allele of the A1032G (rs2070995) polymorphism was associated with increased opioid requirements in postoperative pain [10] and chronic pain [11], however not all studies have shown this association [12, 13]. In opioid substitution therapy for former heroin addicts, increased methadone dose requirements and reduced withdrawal effects were associated with homozygous carriers of the A allele [11].

Methadone is usually prescribed by palliative care specialists as a second choice opioid, for switching from another opioid to improve analgesia and/or reduce adverse effects, and in difficult pain control scenarios including neuropathic pain syndromes and hyperalgesic states [14]. Dosing is challenging, with vigilant dose initiation, adjustment and monitoring required [15]. Methadone is a long acting synthetic opioid and has antagonist activity at the N-methyl-D-aspartate (NMDA) receptor in addition to its activity at the $\mu$ opioid receptor [16]. Despite the many advantages of utilising methadone (low cost, rapid onset of effect, high oral bioavailability and lack of active metabolites), with some suggesting that it may even be effective as a first-line opioid in the management of cancer pain, its prescription is restricted to specialists due to its complex pharmacokinetics and variability in dose requirements and side effects experienced between patients [16].

The aim of this study was to determine any association of KCNJ6 A1032G with opioid requirements and therefore contribution to inter-individual variability in response to methadone for pain management in patients with advanced cancer.

\section{Materials And Methods}

Study participants and procedures Adult patients with advanced cancer who were treated at the oncology and palliative care services of the Mater Adults Hospital (MAH) and St Vincent's Private Hospital (SVPH) in Brisbane between 2013 and 2016 were eligible for inclusion in an open-label dose individualisation study on the use of methadone in pain management. Patient characteristics and clinical data including type of cancer, liver and renal function, and methadone dose were recorded. Pain intensity was assessed using the Brief Pain Inventory [17], where patients were required to rate their pain from 0 to 10 , with a score of 0 representing "no pain" and 10 representing "pain as bad as you can imagine". Methadone was administered via the oral route twice daily with dosing titrated according to patient need by the palliative care specialist. The study was granted ethics approval by MAH (\#HREC/13/MHS/103) and SVPH (\#HREC/13/15) Human Research Ethics Committees. Fifty-four patients who were age $\geq 18$ years, able to read and understand the patient information sheet, able to provide written consent, and willing to provide blood samples were enrolled in the study.

Genotyping Genomic DNA (gDNA) was extracted from whole blood collected into EDTA tubes using an inhouse salting-out method[18] at the Genomics Research Centre, Queensland University of Technology, Brisbane. A NanoDrop ${ }^{\text {TM }}$ ND-1000 spectrophotometer (ThermoFischer Scientific Inc., Waltham, MA, USA) 
was used to measure DNA concentration and purity before dilution to $15-20 \mathrm{ng} / \mu \mathrm{L}$ and storing as stock gDNA at $4^{\circ} \mathrm{C}$. Genotyping of $K C N J 6$ ( $\mathrm{rs} 2070995,1032 \mathrm{~A}>\mathrm{G}$ ) was conducted via pyrosequencing with primers designed using Pyromark Assay Design software (QIAGEN): 5' TTGACAATGGACCCCAACA, 5' TGGTTATGGCTACCGGGTCA (biotinylated) and sequencing primer 5 ' TTAAGAGAAGAATAATTCCC. Pyrosequencing was performed on a QSeq platform (BioMolecular Systems) using Pyromark Gold Q24 reagents (QIAGEN). Sequencing traces were analysed with QSeq software, version 2.1.3 (BioMolecular Systems). All genotyping was conducted by investigators blinded to sample identity.

Statistical analysis Data was analysed using IBM SPSS Statistics for Windows, version 26.0 (Armonk, NY: IBM Corp). Clinical data are described as mean \pm standard deviation (SD) or medians and interquartile ranges, as appropriate for continuous measures. Nominal variables are described as frequencies and percentages. Regression analysis was used to examine whether outcomes were dependent on non-genetic patient characteristics. Deviation of Hardy-Weinberg equilibrium was determined by comparing the observed genotype frequencies with the expected values using the chisquare $\left(\chi^{2}\right)$ test. The Kruskal-Wallis $\mathrm{H}$ test was used to determine whether genotypes were associated with methadone dose or pain score. $\chi^{2}$ analysis was used to determine significant associations for high pain score (>3/10) and high methadone dose (>10 mg/day), when outcomes were categorised. The adequacy of each statistical test was assessed by examining residuals for heterogeneity and normality. Significance was considered if $p<0.05$. The observed minor allele frequency (MAF) was compared to the MAF for relevant populations reported for ALFA and 1000Genomes in dbSNP (National Center for Biotechnology Information) [19].

\section{Results}

Of the 54 adult patients with advanced cancer recruited, complete genotyping data and pain scores were available for 46 participants. Methadone was administered orally, and the prescribed dose ranged from 2.5-50 mg twice daily. Patient characteristics including age, gender, body mass index (BMI) and cancer type are shown in Table 1. The median (IQR) methadone daily dose and patient reported pain score (on a scale of $0-10$ ) for our population was $11.3 \pm 13.9 \mathrm{mg}$ and $3.9 \pm 3.2$, respectively. No patient characteristics were found to significantly determine the outcomes of methadone dose or pain score, including age, gender, height, weight, BMI, liver and renal function (Supplementary Table 1). 


\begin{tabular}{|c|c|c|}
\hline \multicolumn{2}{|c|}{ Patient Characteristic $(n=46)$} & Value \\
\hline $\begin{array}{l}\text { Age } \\
\text { (years) }\end{array}$ & \multirow[t]{3}{*}{ Mean \pm SD (range) } & $\begin{array}{l}60.6 \pm 13.7(32- \\
83)\end{array}$ \\
\hline $\begin{array}{l}\text { Weight } \\
(\mathrm{kg})\end{array}$ & & $\begin{array}{l}68.4 \pm 16.9(36- \\
118)\end{array}$ \\
\hline $\begin{array}{l}\text { BMl } \\
\left(\mathrm{kg} / \mathrm{m}^{2}\right)\end{array}$ & & $\begin{array}{l}24.9 \pm 5.1(16- \\
38.5)\end{array}$ \\
\hline \multirow{2}{*}{$\begin{array}{l}\text { Gender } \\
n(\%)\end{array}$} & Female & $27(58.7)$ \\
\hline & Male & $19(41.3)$ \\
\hline \multirow{10}{*}{$\begin{array}{l}\text { Cancer } \\
\text { type } \\
n(\%)\end{array}$} & Breast & $8(17.4)$ \\
\hline & Colorectal & $8(17.4)$ \\
\hline & Cervical & $6(13.0)$ \\
\hline & Lung & $5(10.9)$ \\
\hline & Mesothelioma & $4(8.7)$ \\
\hline & Endometrial & $3(6.5)$ \\
\hline & Pancreatic & $3(6.5)$ \\
\hline & Prostate & $2(4.3)$ \\
\hline & Multiple myeloma & $2(4.3)$ \\
\hline & $\begin{array}{l}\text { Gallbladder, bladder, liver, periauricular squamous cell carcinoma, } \\
\text { skin cancer }\end{array}$ & $1(2.2)$ \\
\hline
\end{tabular}

Analysis for our study population identified GG $(n=26)$ and GA $(n=20)$ genotypes with no patients identified to be carrying the homozygous AA genotype. The genotype distribution was in agreement with Hardy-Weinberg equilibrium $(p>0.05)$. The MAF for this marker in European populations is reported to be 0.208 (ALFA) and 0.202 (1000Genomes) [19], and is comparable to the observed MAF for our population (0.217). Table 2 provides a summary of the characteristics of studies on the association of KCNJ6 rs2070995 and response to opioids for pain conditions, including chronic pain, post-operative pain and cancer pain, and response to methadone in opioid substitution therapy. Ethnic variance is seen in rs2070995, with the study conducted in Japan observing a MAF of 0.344 [10], which is comparable to the reported MAF for East Asian populations of 0.396 and 0.361 for the ALFA and 1000Genomes databases, respectively [19]. African populations show the lowest MAF with 0.0535 and 0.0068 reported for the ALFA and 1000 Genomes databases, respectively [19]. 
Table 2

Characteristics of studies on the association of KCNJ6 rs2070995 and response to opioids

\begin{tabular}{|c|c|c|c|c|c|}
\hline $\begin{array}{l}\text { Study } \\
\text { reference }\end{array}$ & $\begin{array}{l}\text { Therapeutic } \\
\text { area }\end{array}$ & $\begin{array}{l}\text { Study site, } \\
\text { design and } \\
\text { included } \\
\text { participants }\end{array}$ & Intervention & $\begin{array}{l}\text { Case } \\
\text { numbers } \\
\text { and } \\
\text { MAF* }\end{array}$ & Study findings \\
\hline $\begin{array}{l}\text { Matic et } \\
\text { al. 2017 } \\
\text { [12] }\end{array}$ & $\begin{array}{l}\text { Advanced } \\
\text { cancer }\end{array}$ & $\begin{array}{l}238 \\
\text { advanced } \\
\text { cancer } \\
\text { patients } \\
\text { referred to a } \\
\text { pain } \\
\text { consultation } \\
\text { service due } \\
\text { to } \\
\text { inadequate } \\
\text { analgesia, } \\
\text { Netherlands }\end{array}$ & $\begin{array}{l}\text { Opioids } \\
\text { (fentanyl } 73.3 \% \text {, } \\
\text { oxycodone } 43 \% \text {, } \\
\text { hydromorphone } \\
11 \% \text {, morphine } \\
5 \% \text {, } \\
\text { buprenorphine } \\
5 \% \text { with } 9 \% \\
\text { requiring } \\
\text { ketamine as an } \\
\text { adjuvant } \\
\text { analgesic }\end{array}$ & $\begin{array}{l}\text { GG }(n= \\
10) \\
\text { GA }(n= \\
81) \\
\text { AA }(n= \\
147)\end{array}$ & $\begin{array}{l}\text { No association was } \\
\text { found between } \\
\text { genotypes and } \\
\text { morphine equivalent } \\
\text { dose (MED) or relative } \\
\text { change in MED from } \\
\text { baseline. No } \\
\text { association was found } \\
\text { for use of ketamine as } \\
\text { an adjuvant analgesic. }\end{array}$ \\
\hline $\begin{array}{l}\text { Oosten et } \\
\text { al. } 2016 \\
\text { [13] }\end{array}$ & $\begin{array}{l}\text { Advanced } \\
\text { cancer }\end{array}$ & $\begin{array}{l}335 \\
\text { moderate- } \\
\text { to-severe } \\
\text { cancer- } \\
\text { related pain, } \\
\text { Netherlands }\end{array}$ & $\begin{array}{l}\text { Opioids } \\
\text { (oxycodone, } \\
\text { morphine, } \\
\text { fentanyl, } \\
\text { hydromorphone) }\end{array}$ & $\begin{array}{l}G G(n= \\
215) \\
G A+A A \\
(n=120)\end{array}$ & $\begin{array}{l}\text { No association between } \\
\text { genotypes and opioid } \\
\text { failure, defined as } \\
\text { rotation to another } \\
\text { opioid or treatment with } \\
\text { intrathecal opioids due } \\
\text { to insufficient pain } \\
\text { control and/or side } \\
\text { effects, or the use of } \\
\text { palliative sedation } \\
\text { because of refractory } \\
\text { symptoms associated } \\
\text { with opioid treatment in } \\
\text { the dying phase. }\end{array}$ \\
\hline $\begin{array}{l}\text { Lotsch et } \\
\text { al. 2010 } \\
\text { [11] }\end{array}$ & $\begin{array}{l}\text { Chronic } \\
\text { pain }\end{array}$ & $\begin{array}{l}352 \text { chronic } \\
\text { pain } \\
\text { patients } \\
\text { treated for } \\
\text { pain of } \\
\text { various } \\
\text { reasons in } \\
\text { tertiary } \\
\text { outpatient } \\
\text { care, } \\
\text { Germany }\end{array}$ & $\begin{array}{l}\text { Opioids } \\
\text { (morphine, } \\
\text { fentanyl, } \\
\text { buprenorphine, } \\
\text { oxycodone, } \\
\text { tilidine, } \\
\text { tramadol, } \\
\text { hydromorphone, } \\
\text { dihydrocodeine, } \\
\text { levomethadone, } \\
\text { piritramide) }\end{array}$ & $\begin{array}{l}\mathrm{AA}(\mathrm{n}= \\
17) \\
\mathrm{MAF}= \\
0.2\end{array}$ & $\begin{array}{l}\text { AA genotype associated } \\
\text { with a significantly } \\
\text { higher oral MED than } \\
\text { combined AG and GG } \\
\text { genotypes, with no } \\
\text { significant difference in } \\
\text { AA genotype } \\
\text { distribution for pain } \\
\text { diagnoses or opioid } \\
\text { used, and no significant } \\
\text { difference in pain score. }\end{array}$ \\
\hline
\end{tabular}




\begin{tabular}{|c|c|c|c|c|c|}
\hline $\begin{array}{l}\text { Study } \\
\text { reference }\end{array}$ & $\begin{array}{l}\text { Therapeutic } \\
\text { area }\end{array}$ & $\begin{array}{l}\text { Study site, } \\
\text { design and } \\
\text { included } \\
\text { participants }\end{array}$ & Intervention & $\begin{array}{l}\text { Case } \\
\text { numbers } \\
\text { and } \\
\text { MAF* }\end{array}$ & Study findings \\
\hline $\begin{array}{l}\text { Margarit } \\
\text { et al. } 2019 \\
\text { [20] }\end{array}$ & $\begin{array}{l}\text { Chronic } \\
\text { pain }\end{array}$ & $\begin{array}{l}222 \text { patients } \\
\text { with chronic } \\
\text { lower back } \\
\text { pain } \\
\text { referred for } \\
\text { opioid } \\
\text { prescription, } \\
\text { Spain }\end{array}$ & $\begin{array}{l}\text { Opioids } \\
\text { (fentanyl, } \\
\text { tramadol, } \\
\text { oxycodone, } \\
\text { morphine, } \\
\text { tapentadol, } \\
\text { buprenorphine) }\end{array}$ & $\begin{array}{l}\text { AA }(n= \\
63) \\
\text { AG }(n= \\
33) \\
\text { GG }(=5) \\
M A F= \\
0.21\end{array}$ & $\begin{array}{l}\text { Carriers of the A allele } \\
\text { (AA and } A G \text { ) were } \\
\text { associated with a } \\
\text { significantly higher pain } \\
\text { intensity at the final } \\
\text { visit and at the follow } \\
\text { up visit ( } 2-4 \text { years } \\
\text { later) than the GG } \\
\text { genotype. }\end{array}$ \\
\hline $\begin{array}{l}\text { Bruehl et } \\
\text { al. } 2013 \\
\text { [5] }\end{array}$ & $\begin{array}{l}\text { Post- } \\
\text { operative } \\
\text { pain }\end{array}$ & $\begin{array}{l}311 \text { white } \\
\text { patients } \\
\text { receiving } \\
\text { opioids } \\
\text { after total } \\
\text { knee } \\
\text { arthroplasty } \\
\text { (TKA), } \\
\text { United } \\
\text { States }\end{array}$ & $\begin{array}{l}\text { Opioids ( } 96.4 \% \\
\text { of orders were } \\
\text { for oral } \\
\text { immediate } \\
\text { release } \\
\text { oxycodone) }\end{array}$ & $\begin{array}{l}\text { MAF = } \\
0.229\end{array}$ & $\begin{array}{l}\text { No association between } \\
\text { genotypes and total } \\
\text { number of oral opioid } \\
\text { analgesic medication } \\
\text { orders for patients } \\
\text { undergoing TKA. It was } \\
\text { not possible in the } \\
\text { study to examine the } \\
\text { number of individual } \\
\text { analgesic medication } \\
\text { doses actually } \\
\text { administered or directly } \\
\text { assess their efficacy. }\end{array}$ \\
\hline $\begin{array}{l}\text { Nishizawa } \\
\text { et al. } 2009 \\
\text { [10] }\end{array}$ & $\begin{array}{l}\text { Post- } \\
\text { operative } \\
\text { pain }\end{array}$ & $\begin{array}{l}129 \\
\text { undergoing } \\
\text { major open } \\
\text { abdominal } \\
\text { surgery } \\
\text { (mostly } \\
\text { gastrectomy } \\
\text { for gastric } \\
\text { cancer and } \\
\text { colectomy } \\
\text { for } \\
\text { colorectal } \\
\text { cancer), } \\
\text { Japan }\end{array}$ & $\begin{array}{l}\text { Continuous } \\
\text { epidural } \\
\text { fentanyl or } \\
\text { morphine } \\
\text { diluted with } \\
\text { bupivacaine. } \\
\text { Opioids } \\
\text { (morphine, } \\
\text { buprenorphine, } \\
\text { pentazocine, } \\
\text { pethidine) } \\
\text { and/or NSAIDS } \\
\text { used for rescue } \\
\text { analgesia. }\end{array}$ & $\begin{array}{l}\text { AA }(n= \\
11) \\
\text { AG }(n= \\
62) \\
\text { GG }(n= \\
56) \\
\text { MAF }= \\
0.344\end{array}$ & $\begin{array}{l}\text { AA genotype required } \\
\text { rescue pain medication } \\
\text { more frequently than } \\
\text { AG and GG genotypes, } \\
\text { with no associations for } \\
\text { postsurgical pain } \\
\text { ratings observed. A } \\
\text { trending increase in oral } \\
\text { MED was seen for AA } \\
\text { genotypes, which was } \\
\text { significant for female } \\
\text { patients. }\end{array}$ \\
\hline $\begin{array}{l}\text { Lotsch et } \\
\text { al. 2010 } \\
\text { [11] }\end{array}$ & $\begin{array}{l}\text { Opioid } \\
\text { substitution } \\
\text { therapy }\end{array}$ & $\begin{array}{l}85 \text { patients } \\
\text { on } \\
\text { methadone } \\
\text { substitution } \\
\text { therapy for } \\
\text { heroin } \\
\text { addiction, } \\
\text { Germany }\end{array}$ & Methadone & $\begin{array}{l}A A(n= \\
4) A G(n \\
=12) G G \\
(n=69) \\
M A F= \\
0.22\end{array}$ & $\begin{array}{l}\text { AA genotype had } \\
\text { significantly higher } \\
\text { average and maximum } \\
\text { daily methadone doses } \\
\text { during the first year of } \\
\text { substitution therapy } \\
\text { than combined AG and } \\
\text { GG genotypes, and AA } \\
\text { carriers lacked opioid } \\
\text { withdrawal symptoms. }\end{array}$ \\
\hline
\end{tabular}


The genotype frequencies and methadone daily dose and patient reported pain score are shown in Table 3. No significant associations were shown for methadone dose or pain score between genotypes when treated as continuous variables $(p>0.05)$. No significant association was shown between genotypes for low $(\leq 3 / 10)$ or high $(>3 / 10)$ pain scores, or low $(\leq 10 \mathrm{mg} /$ day $)$ or high $(>10 \mathrm{mg} /$ day $)$ methadone dose $(p>0.05)$. These findings are consistent with other studies in advanced cancer, where Matic et al. [12] and Oosten et al. [13] found no associations for their European populations (Table 2). For studies in chronic pain, Lotsch et al. [11] reported the AA genotype to be associated with a significantly higher opioid requirements than combined AG and GG genotypes, and Margarit et al. [20] reported that carriers of the $A$ allele ( $A A$ and $A G$ ) were associated with a significantly higher pain intensity than those carrying the GG genotype. In post-operative pain, Nishizawa et al. [10] reported the AA genotype to require rescue pain medication more frequently than $A G$ and $G G$ genotypes, with no associations for postsurgical pain ratings, while Bruehl et al. [5] reported no association between genotype and total number of oral opioid analgesic medication orders for patients undergoing total knee arthroplasty. A study in patients receiving methadone maintenance therapy reported that homozygous carriers of the A allele required more methadone yet had fewer withdrawal symptoms than the heterozygous AG and GG genotypes [11].

Table 3

Methadone dose and pain score for each genotype

\begin{tabular}{|c|c|c|c|c|}
\hline Phenotype outcome measure & Genotype & Value & Statistic & $p$ value \\
\hline Methadone dose (mg/day) & GG & $10.0 \pm 10.0(4.0,58.3)$ & \multirow[t]{2}{*}{$H=0.002$} & \multirow[t]{2}{*}{$0.965^{a}$} \\
\hline Median $\pm I Q R(\min , \max )$ & $\mathrm{GA}$ & $13.8 \pm 19.5(3.8,93.3)$ & & \\
\hline \multirow{2}{*}{$\begin{array}{l}\text { Low dose ( } \leq 10 \mathrm{mg} / \text { day }) \\
n(\%)\end{array}$} & GG & $14(60.9)$ & \multirow[t]{4}{*}{$\chi^{2}=0.354$} & \multirow[t]{4}{*}{$0.552^{b}$} \\
\hline & GA & $9(39.1)$ & & \\
\hline \multirow{2}{*}{$\begin{array}{l}\text { High dose (> 10mg/day) } \\
n(\%)\end{array}$} & GG & $12(52.2)$ & & \\
\hline & $\mathrm{GA}$ & $11(47.8)$ & & \\
\hline Pain score $(0-10)$ & GG & $3.8 \pm 3.3(0.7,7.1)$ & \multirow[t]{2}{*}{$H=0.0005$} & \multirow[t]{2}{*}{$0.982^{a}$} \\
\hline Median $\pm I Q R(\min , \max )$ & GA & $3.9 \pm 2.8(0,8.0)$ & & \\
\hline \multirow{2}{*}{$\begin{array}{l}\text { Low pain score }(\leq 3 / 10) \\
n(\%)\end{array}$} & GG & $12(60.0)$ & \multirow[t]{4}{*}{$\chi^{2}=0.174$} & \multirow[t]{4}{*}{$0.676^{b}$} \\
\hline & GA & $8(40.0)$ & & \\
\hline \multirow{2}{*}{$\begin{array}{l}\text { High pain score }(>3 / 10) \\
n(\%)\end{array}$} & GG & $14(53.8)$ & & \\
\hline & $\mathrm{GA}$ & $12(46.2)$ & & \\
\hline
\end{tabular}

\section{Discussion}


Polymorphisms in KCNJ6 have not been widely investigated [5]. This is the first association study on opioid response in patients with advanced cancer, where methadone has been used as the therapeutic intervention. Only one study has previously investigated association between methadone dose requirements and polymorphisms in KCNJ6 (rs2070995), reporting a significant association for 85 patients on opioid substitution therapy [11]. Two studies have been conducted in patients with advanced cancer, and consistent with our findings, both have reported no association for rs2070995 and opioid response $[12,13]$. Mixed results were seen for studies in postoperative pain $[5,10]$, and associations were shown for two studies in chronic pain, reporting carriers of the A allele to be associated with a significantly higher pain intensity [20] and higher opioid requirements [11].

Several studies have also been conducted for different polymorphisms in KCNJ6. Nishizawa et al. [21] investigated 27 SNPs and reported that rs2835859 may serve as a marker that predicts sensitivity to analgesia and pain. Carriers of the $C$ allele required less postoperative fentanyl after cosmetic orthognathic surgery in a study on healthy participants $(n=355)$, and this finding was substantiated in a further study by the same authors of 500 healthy participants, where $C$ allele carriers were found to have less pain perception than non-carriers, for cold pressor and mechanically-induced pain tests [21].

Elens et al. [22] investigated the association of rs6517442 and opioid requirements (morphine or remifentanil) in 34 preterm infants requiring endotracheal intubation, reporting that those with the AA genotype needed more time to reach a pain-free state after intubation than infants with the AG or GG genotypes. This finding was consistent with Margarit et al. [20] and Nishizawa et al. [10] (Table 2), who also investigated rs6517442 and reported similar associations for carriers of the A allele and pain intensity [20], or requirement for rescue analgesia [10]. The study by Matic et al. [12], however, reported no associations for rs6517442. A candidate gene replication study in paediatric postoperative pain including children of African American $(n=241)$ and European Caucasian $(n=277)$ ancestry, also showed association for rs6517442, in addition to polymorphisms in rs928723, rs2211843, rs2835925, rs2835930 in the same direction for various pain phenotypes across both ethnicities in postoperative pain managed with morphine [23].

Caution is advised when interpreting findings of our study and those reviewed for clinical application, especially when considering the heterogeneity of phenotype outcome measures across studies, which ranged from opioid dose, pain relief, the need for opioid rotation, pain intensity, number of analgesic medication orders, and the requirement for rescue analgesia. A wide variety of opioids were also used across studies as the treatment intervention, in some cases in addition to other analgesics including nonsteroidal anti-inflammatory drugs and anticonvulsants (gabapentin, pregabalin). Further studies are needed with larger sample sizes and consistent phenotype outcome measures to provide convincing evidence that polymorphisms in $K C N J 6$ contribute to inter-patient variability in opioid response in palliative care. Ethnic variance in allele frequencies in polymorphisms in $K C N J 6$ may also account for the mixed results in association studies, with significant differences seen in the MAF for African, Asian and European populations [19], highlighting the importance of taking ancestry into account when considering individual dosing considerations in the clinical setting. 


\section{Conclusion}

Consistent with two other studies on opioid response in advanced cancer, our study showed no significant association for the polymorphism in KCNJ6 rs2070995 and response to methadone for pain management. Associations have been shown for opioid response in chronic pain and opioid substitution therapy, with mixed results seen for post-operative pain, however studies are few. As the technology in pharmacogenomic testing becomes more accessible and economical, the ability for pain management therapy to be guided by precision genomic information provides a promising area for improving quality of life in palliative care [4]. However, further research is required before convincing evidence can show that polymorphisms in $K C N J 6$ contribute to inter-patient variability in opioid response in palliative care.

\section{Declarations}

\section{Funding}

Partial financial support was received from Griffith University, The Mater Palliative Care Research Fund and St Vincent's Hospital Brisbane, Australia. The study did not receive any funding from third parties.

\section{Acknowledgments}

The authors gratefully acknowledge the patients who agreed to participate in this study and the clinical staff at Mater Adults Hospital and St Vincent's Private Hospital.

\section{Author contribution}

Alison Haywood, Larisa Haupt, Janet Hardy and Phillip Good contributed to the study conception and design. All authors contributed to the formal analysis and interpretation of the data. All authors contributed to the drafting of the work or revising it critically for content. All authors have read and approved the final manuscript.

\section{Ethics approval}

This study was performed in line with the principles of the Declaration of Helsinki. Approval was granted by the Human Research Ethics Committees at Mater Health Services (\# HREC/13/MHS/103), St Vincent's Health and Aged Care (\#HREC/13/15) and Griffith University (\#PHM/17/13/HREC).

\section{Consent to participate}

Informed consent was obtained from all individual participants included in the study. 


\section{Consent for publication}

Patients provided written informed consent acknowledging that their data would be used for research publication.

\section{Conflict of interest}

The authors have no relevant financial or non-financial interests to disclose. The authors have no conflicts of interest to declare that are relevant to the content of this article.

\section{Data accessibility}

All data generated or analysed during this study are included in this published article (and its supplementary information files).

\section{References}

1. Wiffen PJ, Wee B, Derry S, Bell RF, Moore RA (2017) Opioids for cancer pain - an overview of Cochrane reviews. Cochrane Database Syst Rev 7: CD012592. DOI 10.1002/14651858.CD012592.pub2

2. World Health Organization (2018) WHO guidelines for the pharmacological and radiotherapeutic management of cancer pain in adults and adolescents. World Health Organization, Geneva

3. Bugada D, Lorini LF, Fumagalli R, Allegri M (2020) Genetics and opioids: Towards more appropriate prescription in cancer pain. Cancers (Basel) 12: 1951. DOI 10.3390/cancers 12071951

4. Patel JN, Wiebe LA, Dunnenberger HM, McLeod HL (2018) Value of supportive care pharmacogenomics in oncology practice. Oncologist 23: 956-964. DOI 10.1634/theoncologist.20170599

5. Bruehl S, Denton JS, Lonergan D, Koran ME, Chont M, Sobey C, Fernando S, Bush WS, Mishra P, Thornton-Wells TA (2013) Associations between KCNJ6 (GIRK2) gene polymorphisms and painrelated phenotypes. Pain 154: 2853-2859. DOI 10.1016/j.pain.2013.08.026

6. Hibino H, Inanobe A, Furutani K, Murakami S, Findlay I, Kurachi Y (2010) Inwardly rectifying potassium channels: their structure, function, and physiological roles. Physiol Rev 90: 291-366. DOI 10.1152/physrev.00021.2009

7. Nishizawa D, Gajya N, Ikeda K (2011) Identification of selective agonists and antagonists to G protein-activated inwardly rectifying potassium channels: candidate medicines for drug dependence and pain. Curr Neuropharmacol 9: 113-117. DOI 10.2174/157015911795017227

8. Walsh KB (2011) Targeting GIRK channels for the development of new therapeutic agents. Front Pharmacol 2: 64. DOI 10.3389/fphar.2011.00064 
9. Marker CL, Stoffel M, Wickman K (2004) Spinal G-protein-gated K+ channels formed by GIRK1 and GIRK2 subunits modulate thermal nociception and contribute to morphine analgesia. J Neurosci 24: 2806-2812. DOI 10.1523/JNEUROSCI.5251-03.2004

10. Nishizawa D, Nagashima M, Katoh R, Satoh Y, Tagami M, Kasai S, Ogai Y, Han W, Hasegawa J, Shimoyama N, et al. (2009) Association between KCNJ6 (GIRK2) gene polymorphisms and postoperative analgesic requirements after major abdominal surgery. PLoS One 4: e7060. DOI 10.1371 /journal.pone.0007060

11. Lotsch J, Pruss H, Veh RW, Doehring A (2010) A KCNJ6 (Kir3.2, GIRK2) gene polymorphism modulates opioid effects on analgesia and addiction but not on pupil size. Pharmacogenet Genomics 20: 291-297. DOI 10.1097/FPC.0b013e3283386bda

12. Matic M, Jongen JL, Elens L, de Wildt SN, Tibboel D, Sillevis Smitt PA, van Schaik RH (2017) Advanced cancer pain: The search for genetic factors correlated with interindividual variability in opioid requirement. Pharmacogenomics 18: 1133-1142. DOI 10.2217/pgs-2017-0060

13. Oosten AW, Matic M, van Schaik RH, Look MP, Jongen JL, Mathijssen RH, van der Rijt CC (2016) Opioid treatment failure in cancer patients: The role of clinical and genetic factors. Pharmacogenomics 17: 1391-1403. DOI 10.2217/pgs-2016-0082

14. Mercadante S, Bruera E (2018) Methadone as a first-line opioid in cancer pain management: A systematic review. J Pain Symptom Manage 55: 998-1003. DOI 10.1016/j.jpainsymman.2017.10.017

15. Good P, Afsharimani B, Movva R, Haywood A, Khan S, Hardy J (2014) Therapeutic challenges in cancer pain management: A systematic review of methadone. J Pain Palliat Care Pharmacother 28: 197-205. DOI 10.3109/15360288.2014.938883

16. Nicholson AB, Watson GR, Derry S, Wiffen PJ (2017) Methadone for cancer pain. Cochrane Database Syst Rev: CD003971. DOI 10.1002/14651858.CD003971.pub4

17. Cleeland CS, Ryan KM (1994) Pain assessment: global use of the Brief Pain Inventory. Ann Acad Med Singap 23: 129-138

18. Chacon-Cortes D, Haupt LM, Lea RA, Griffiths LR (2012) Comparison of genomic DNA extraction techniques from whole blood samples: a time, cost and quality evaluation study. Molecular biology reports 39: 5961-5966. DOI 10.1007/s11033-011-1408-8

19. National Library of Medicine National Center for Biotechnology. Single Nucleotide Polymorphism Database. Reference SNP report rs2070995. https://www.ncbi.nlm.nih.gov/snp/rs2070995 Accessed 10 November 2021.

20. Margarit C, Roca R, Inda MD, Muriel J, Ballester P, Moreu R, Conte AL, Nunez A, Morales D, Peiro AM (2019) Genetic contribution in low back pain: A prospective genetic association study. Pain Pract 19: 836-847. DOI 10.1111/papr.12816

21. Nishizawa D, Fukuda K, Kasai S, Ogai Y, Hasegawa J, Sato N, Yamada H, Tanioka F, Sugimura H, Hayashida M, et al. (2014) Association between KCNJ6 (GIRK2) gene polymorphism rs2835859 and 
post-operative analgesia, pain sensitivity, and nicotine dependence. J Pharmacol Sci 126: 253-263.

DOI 10.1254/jphs.14189fp

22. Elens L, Norman E, Matic M, Rane A, Fellman V, van Schaik RH (2016) Genetic predisposition to poor opioid response in preterm infants: Impact of KCNJ6 and COMT polymorphisms on pain relief after endotracheal intubation. Ther Drug Monit 38: 525-533. DOI 10.1097/FTD.0000000000000301

23. Li J, Wei Z, Zhang J, Hakonarson H, Cook-Sather SD (2019) Candidate gene analyses for acute pain and morphine analgesia after pediatric day surgery: African American versus European Caucasian ancestry and dose prediction limits. Pharmacogenomics J 19: 570-581. DOI 10.1038/s41397-0190074-4

\section{Supplementary Files}

This is a list of supplementary files associated with this preprint. Click to download.

- SupplementaryTable1.docx 